\title{
Aydın ve Denizli'deki Sıcak Su Kaynaklarından İzole Edilen Termofilik Bakterilerin Lipaz, Amilaz ve Proteaz Aktivitelerinin Araştırılması
}

\author{
Mehmet Aytar $^{1 *}$, Bülent Bozdoğan², Gamze Başbülbül ${ }^{3}$ \\ 1*Aydın Adnan Menderes Üniversitesi, Fen Bilimleri Enstitüsü, Biyoloji Bölümü, Aydın, Türkiye,(ORCID: 0000-0002-8083-7358), maytar90@gmail.com.tr \\ ${ }^{2}$ Aydın Adnan Menderes Üniversitesi, Tıp Fakültesi, Tıbbi Mikrobiyoloji Bölümü, Aydın, Türkiye (ORCID: 0000-0003-2469-9728), bbozdogan@gmail.com.tr \\ ${ }^{3}$ Aydın Adnan Menderes Üniversitesi, Fen Edebiyat Fakültesi, Biyoloji Bölümü, Aydın, Türkiye (ORCID: 0000-0001-8151-6321), gbasbulbul@adu.edu.tr
}

(Illk Geliş Tarihi 25 Ağustos 2021 ve Kabul Tarihi 25 Eylül 2021)

(DOI: $10.31590 /$ ejosat.987198)

ATIF/REFERENCE: Aytar, M., Bozdoğan, B. \& Başbülbül, G. (2021). Aydın ve Denizli’deki Sıcak Su Kaynaklarından İzole Edilen Termofilik Bakterilerin Lipaz, Amilaz ve Proteaz Aktivitelerinin Araştırılması. Avrupa Bilim ve Teknoloji Dergisi, (27), 570-574.

$\ddot{\mathbf{O} z}$

Termofilik bakteriler sıcak çevrelerde gelişebilen mikroorganizmalardır. Bu bakterilerin ürettikleri enzimler bitki ve hayvan kaynaklı enzimlere göre daha stabil olabilmekte ve daha ucuz olarak elde edilmektedirler. Termostabil enzimler ekstrem şartlarda esneklik ve tolerans göstermektedirler. Lipazlar biyoteknoloji ile ilişkili önemli gruplardır ve gıda, mandıra, deterjan ve ilaç endüstrisinde kullanılmaktadırlar. Diğer önemli bir enzim grubu olan amilazlar kağıt, şeker, tekstil, deterjan, firında pişirme ve demleme endüstrisi gibi çeşitli alanlarda kullanılmaktadır. Proteazlar hidrolitik enzimlerdir ve deterjan üretimi, deri ürünleri, ilaç, et yumuşatıcı olarak, gıda ürünleri ve katı atık arıtma sanayii gibi çeşitli endüstriyel işlemlerde kullanılmaktadır. Bu çalışmada, Aydın ve Denizli'deki bazı termal alanlardan elde edilen 30 suşun $16 \mathrm{~S}$ rDNA bölgeleri PCR ile çoğaltılmış ve moleküler tanıları yapılmıştır. Otuz izolat arasında suşların $\%$ 50'si lipaz, \% 63.3'ü amilaz, \% 56.6'sı proteaz enzimlerini üretmektedirler. Lipaz-proteaz üreten üç, amilaz-proteaz üreten yedi izolat saptanırken, her üç enzimi de üreten altı izolat olduğu belirlenmiştir. Sonuç olarak, çalışmamızda elde edilen suşlar ve ürettikleri enzimler endüstriyel biyoteknolojide kullanılma potansiyeline sahiptir.

Anahtar Kelimeler: Termofilik Bakteriler, Lipaz, Amilaz, Proteaz, 16S rDNA.

\section{Lipase, Amylase and Protease Activities of Thermophilic Bacteria Isolated from Hot Springs in Aydin and Denizli}

\begin{abstract}
Thermophilic microorganisms are able to grow at high temperatures. Enzymes produced by these kind of bacteria are more stable and cost effective. Thermostable enzymes have flexibility and tolerance in extreme conditions. Lipases dealing with biotechnology are important groups of enzymes. These enzymes are used in food, dairy, detergent and pharmaceutical industry. Amylases that are also important groups are used in various biotechnological fields such as paper, sugar, textile, detergent, baking and infusion industry. Proteases are hydrolytic enzymes and they are used in various industries such as producing detergent, leather products, pharmaceutical, meat tenderizer, food products and solid waste treatment industry. In this study, $16 \mathrm{~S}$ rDNA regions of thirty bacterial strains isolated from thermal areas in Aydin and Denizli are amplified by PCR and isolates were identified by molecular methods. Among 30 isolates, percentage of strains that produce one enzyme is that; lipase \% 50, amylase \% 63.3, protease $\% 56.6$. Three of strains were found to be produce both Lipase and protease, while seven strains were amylase and protease producers. Six strains were found to capable of producing all three enzymes. As a result, isolates obtained in our study and their enzymes have an important potential in industrial biotechnology.
\end{abstract}

Keywords: Thermophilic Bacteria, Lipase, Amylase, Protease, 16S rDNA.

*Sorumlu Yazar:maytar90@gmail.com.tr 


\section{Giriş}

Termofilik mikroorganizmalar yüksek sıcaklıklarda gelişebilmektedirler. Ekstrem çevrelerde üç farklı sıcaklık aralığında gelişen gruplar (termofiller $35-70{ }^{\circ} \mathrm{C}$, ekstrem termofiller $55-85^{\circ} \mathrm{C}$, hipertermofiller $75-113^{\circ} \mathrm{C}$ ) tespit edilmiştir (Baker ve ark., 2001). Jeotermal kaynaklar açısından ülkemiz oldukça zengindir. Resmi kayıtlara alınmış 140 adet jeotermal alan bulunmaktadır (ANONIM, 2001). Bu bakterilerin ürettiği enzimler bitki ve hayvan kaynaklı enzimlere göre daha stabildirler, fazla üretilebilmekte ve ucuz olarak elde edilmektedirler. Termostabil enzimler ekstrem şartlara karş1 esneklik ve tolerans göstermektedirler (Güven, 2011). Termofilik bakteriler tarafından üretilen birçok enzim bulunmaktadır. $\mathrm{Bu}$ çalışmada, biyoteknolojide çok kullanılan lipaz, amilaz ve proteaz enzimleri çalışılmıştır. Lipazlar biyoteknoloji ile ilişkili önemli gruplardır ve gıda, mandıra, deterjan ve ilaç endüstrisinde kullanılmaktadırlar (Royter ve ark., 2009). Diğer önemli grup olan amilazlar da çeşitli biyoteknolojik alanlarda örneğin, kağıt, şeker, tekstil, deterjan, firında pişirme ve demleme endüstrisinde kullanılmaktadır (de Souza \& Magalhães, 2010). Proteazlar hidrolitik enzimlerdir. Proteinlerin daha küçük yapılı peptid ve aminoasitlere parçalanmasını hızlandırmaktadırlar. Proteazların kullanımı deterjan üretimi, deri ürünleri, ilaç, et yumuşatıcı olarak, gıda ürünleri ve katı atık arıtma sanayii gibi çeşitli endüstriyel işlemlerde kaydadeğer artış göstermiştir (Fıtrıanı, 2018). Endüstride çalışma sıcaklığı yüksek olabilmektedir. Termofilik olmayan enzimler kullanıldığında aktivite kaybı yaşanmaktadır. Bu yüzden birçok alanda termofilik enzimlere ihtiyaç duyulmaktadır. Çalışmamızda Aydın ve Denizli çevresindeki termal alanlardan alınan sıcak su ve çamur örneklerinden elde edilen izolatlardaki lipaz, amilaz ve proteaz enzim aktivitelerine bakılmıştır.

\section{Materyal ve Metot}

\subsection{Materyal}

Hasköy, Kabaağaç, Pamukkale (Denizli), Buharkent ve Ortakçı (Aydın)'da bulunan kaynaklardan su ve çamur örnekleri steril kaplara alınmıştır. Örneklerin pH'ları ve sıcaklıkları yerinde ölçülmüş lokasyon koordinatları kaydedilmiştir (Tablo 1) Arazi sonrası laboratuvara getirilen örneklerden aynı gün içerisinde ekimler yapılmıştır.

Tablo 1. Örneklerin pH, Sicaklık ve Lokasyon Koordinatları

\begin{tabular}{|l|l|l|l|}
\hline İstasyon & Sicaklık & $\mathbf{p H}$ & Koordinatlar \\
\hline Pamukkale Traverten & $22^{\circ} \mathrm{C}$ & 7,0 & $\begin{array}{l}37^{\circ} 55^{\prime} 11^{\prime \prime} \mathrm{N} \\
29^{\circ} 07^{\prime} 26^{\prime \prime} \mathrm{E}\end{array}$ \\
\hline Hasköy İnaltı (Denizli) & $60^{\circ} \mathrm{C}$ (Çamur) & 7,0 & $\begin{array}{l}37^{\circ} 55^{\prime} 36^{\prime \prime} \mathrm{N} \\
28^{\circ} 48^{\prime} 29^{\prime \prime} \mathrm{E}\end{array}$ \\
\hline Umut Termal (Denizli) & $\begin{array}{l}62^{\circ} \mathrm{C} \\
(\mathrm{Alt} \text { Havuz) }\end{array}$ & 10,0 & $\begin{array}{l}37^{\circ} 55^{\prime} 17^{\prime \prime} \mathrm{N} \\
28^{\circ} 49^{\prime} 43^{\prime \prime} \mathrm{E}\end{array}$ \\
\hline Umut Termal (Denizli) & $40^{\circ} \mathrm{C}$ & 7,0 & $\begin{array}{l}37^{\circ} 55^{\prime} 14^{\prime \prime} \mathrm{N} \\
28^{\circ} 49^{\prime} 41^{\prime \prime} \mathrm{E}\end{array}$ \\
\hline Kayta Otel (Buharkent) & $47^{\circ} \mathrm{C}$ (Musluk) & 10,0 & $\begin{array}{l}37^{\circ} 56^{\prime} 50^{\prime \prime} \mathrm{N} \\
28^{\circ} 49^{\prime} 43^{\prime \prime} \mathrm{E}\end{array}$ \\
\hline $\begin{array}{l}\text { Güney Termal Otel } \\
\text { (Buharkent) }\end{array}$ & $61^{\circ} \mathrm{C}$ (Musluk) & 10,0 & $\begin{array}{l}37^{\circ} 56^{\prime} 48^{\prime \prime} \mathrm{N} \\
28^{\circ} 49^{\prime} 42^{\prime \prime} \mathrm{E}\end{array}$ \\
\hline $\begin{array}{l}\text { Ortakç1 } \\
\text { (Aydın) }\end{array}$ & $32^{\circ} \mathrm{C}$ (Çamur) & 7,0 & $\begin{array}{l}37^{\circ} 58^{\prime} 29^{\prime \prime} \mathrm{N} \\
28^{\circ} 42^{\prime} 47^{\prime \prime} \mathrm{E}\end{array}$ \\
\hline
\end{tabular}

\subsection{Termofilik Bakterilerin İzole Edilmesi ve Saflaştırılması}

Denizli ve çevresinden toplanan sıcak su ve çamur örneklerinden 1/9 oranında fizyolojik tuzlu su (FTS) ile dilüsyon yapılarak eküvyon çubuğu ile TSA besiyerine yayma ekim yapılmıştır. $50^{\circ} \mathrm{C}$ 'de gecelik inkübasyona bırakılmıştır. Karışık bakteri kolonilerinden en az iki pasaj ile saflaştırma yapılarak 30 izolat elde edilmiştir.

\subsection{DNA İzolasyonu ve 16S rDNA PCR}

Saflaştırılan suşlardan easyDNA, DNA izolasyon kiti (RTech, Türkiye) ile total DNA izolasyonu yapılmıştır. Total DNA' dan 16S rDNA korunmuş gen bölgeleri, 16S 20F (5'AGAGTTTGATCCTGGCTCAG-3')-1390R (5' GACGGGCGGTGTGTACAA-3') primerleri ile amplifiye edilmiştir. PCR reaksiyonu, $94^{\circ} \mathrm{C} 4 \mathrm{dk},\left(94{ }^{\circ} \mathrm{C} 30 \mathrm{sn}, 56{ }^{\circ} \mathrm{C} 30 \mathrm{sn}\right.$, $\left.72{ }^{\circ} \mathrm{C} 1 \mathrm{dk}\right) 35$ döngü, $72{ }^{\circ} \mathrm{C} 7 \mathrm{dk}$ şartlarında yapılmıştır. PCR master mix içeriğinde; final konsantrasyon olarak $1 \mathrm{x}$ taq buffer $\left\{+\left(\mathrm{NH}_{4}\right) \mathrm{SO}_{4},-\mathrm{MgCl}_{2}\right\}, 25$ unit/mL Taq DNA polimeraz, dNTP(10mM), 16S rDNA primerleri (100 pmol), $\operatorname{MgCl}_{2}(2 \mathrm{mM})$ kullanılmıştır. PCR reaksiyonundan sonra amplikonlar istenilen DNA'nın amplifiye edilip edilmediğini anlamak için agaroz jel elektroforezinde her kuyuya $5 \mu \mathrm{l}$ DNA eklenip $30 \mathrm{dk}$ yürütülmüştür. Marker olarak $\lambda$ Pst marker kullanılmıştır. Sonuç UV Transillumunatörde UV ışıkta gözlemlenmiştir.

\subsection{RFLP}

Elde edilen 30 izolatın 16S rDNA PCR amplikonları Nla III ve Rsa I restriksiyon enzimleri ile kesilmiştir. Reaksiyon için:

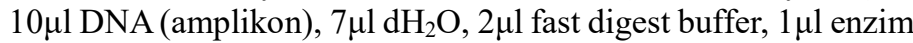
kullanılmıştır. Termal çalkalayıcıda $37^{\circ} \mathrm{C}$ 'de $30 \mathrm{dk}$ inkübe edilmiştir. İşlem sonunda DNA agaroz jel elektroforezinde yürütülmüş ve oluşan bant profilleri değerlendirilerek farklı bant profiline sahip suşlar sekans analizi için seçilmiştir.

\subsection{Sekans Analizi}

RFLP sonucu farklı DNA profiline sahip olduğu belirlenen 8 izolatın 16S rDNA fragmanlarının dizi analizi hizmet alımı ile yaptırılmıştır (MedSantek). Diziler BLAST analizi ile veritabanındaki diziler ile karşılaştırılmış ve moleküler tanı için homolojiler belirlenmiştir (blast.ncbi.nlm.nih.gov/Blast.cgi)

\subsection{Enzim Aktivitelerinin Kalitatif Tayini}

İzole edilen 30 izolatın lipaz, amilaz, proteaz aktiviteleri taranmıştır. Lipaz enzimi tayini için Tween 20 agar $((\mathrm{g} / \mathrm{L}) ; 10 \mathrm{~g}$ pepton, $5 \mathrm{~g} \mathrm{NaCl}, 0.1 \mathrm{~g} \mathrm{CaCl}_{2} \cdot 2 \mathrm{H}_{2} \mathrm{O}, 20 \mathrm{~g}$ agar ve $10 \mathrm{ml}(\mathrm{v} / \mathrm{v})$ Tween 20) (Ramnath ve ark., 2017), amilaz tayini için Nişasta agar (\%0.01 $\mathrm{CaCl}_{2}, \% 0.5$ nişasta ve TSA besiyeri) (Başbülbül ve ark., 2018) ve proteaz tayini için Skim milk agar (20g/L skim milk tozu ve TSA besiyeri) kullanılmıştır. İzolatlar besiyerlerine ekildikten sonra $50^{\circ} \mathrm{C}$ 'de inkübe edilmişlerdir. Besiyerlerinde gelișim gösteren bakteri kolonilerinin etrafında hale şeklindeki zonların oluşması enzim aktivitesi göstergesi olarak kabul edilmiştir. Ertesi gün oluşan zon varlığına ve boyutuna göre aktiviteler kalitatif olarak değerlendirilmiştir. Oluşan zon büyüklükleri izolatlar arasında gözleme dayalı karşılaştırılarak büyük $(+++)$ orta(++) ve küçük (+) olarak değerlendirilmişlerdir. 


\section{Araştırma Sonuçları ve Tartışma}

Çalışmada izole edilen 30 suşun $16 \mathrm{~S}$ rDNA PCR amplikonlarından RFLP metodu ile farklı profillere sahip olduğu tespit edilen 8 suşun $16 \mathrm{~S}$ rDNA'sı hizmet alımı yoluyla sekanslatılmıştır. Farklı olan suşların tanısı BLAST analizi (blast.ncbi.nlm.nih.gov/Blast.cgi) yoluyla yapılmıştır. Sonrasında 30 izolatın lipaz, amilaz ve proteaz enzim aktiviteleri tayin edilmiştir. Bulgular sırasıyla aşağıda verilmiştir.

\subsection{RFLP}

İzolatlardan elde edilen 16S rDNA amplikonları RsaI ve NlaIII restriksiyon enzimleri ile kesilerek oluşan bant profilleri değerlendirilmiştir. Otuz izolat arasından 8 farklı bant profili tespit edilmiştir (Şekil 1).

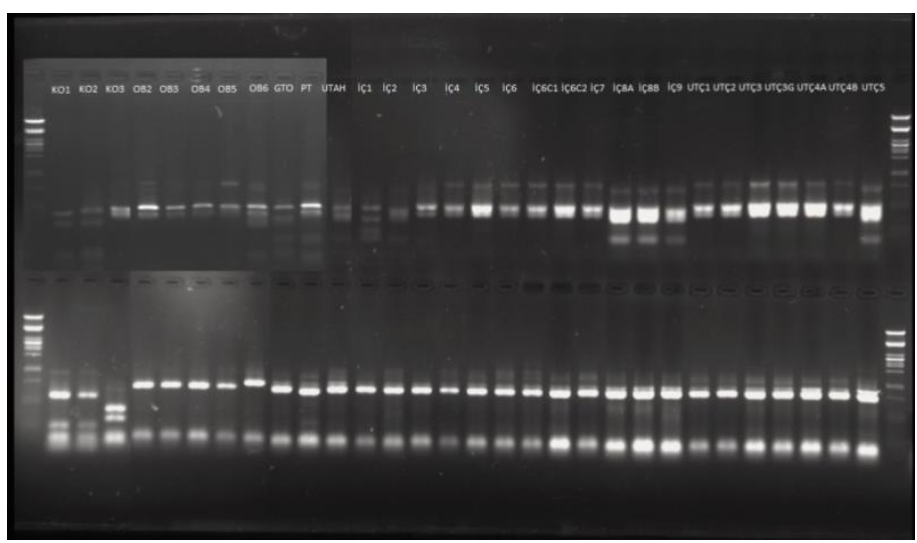

Şekil 1 İzole edilen 30 suşun RsaI (üst) ve NlaIII (alt) restriksiyon enzimleri ile kesimi

RFLP sonucuna göre tayin edilen gruplar ve izolat kodları Tablo 2'de verilmiştir.

\subsection{Sekans Analizi}

Sekiz adet grup içerisinde yer alan izolatlardan birer tane seçilerek, 16S rDNA dizi analizi yapılmıştır. Sekans sonuçlarına göre tespit edilen homolojiler Tablo 2 de verilmiştir.
Tablo 2. RFLP Sonucu Seçilen 8 Farklı İolatın $16 S$ rDNA Sekanslama Sonucu

\begin{tabular}{|c|c|c|c|}
\hline 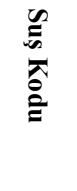 & 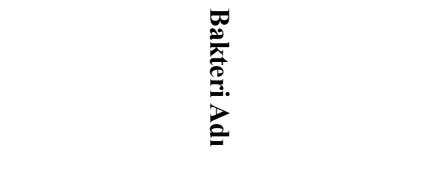 & 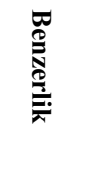 & 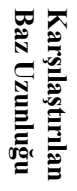 \\
\hline KO1 & $\begin{array}{l}\text { Tepidicella xavieri TU-16 } \\
\qquad \underline{(16585714)}\end{array}$ & $\% 97$ & 700 \\
\hline KO3 & $\begin{array}{c}\text { Paracoccus aestuarii KNUC9015 } \\
\text { (吕505949) }\end{array}$ & $\% 99$ & 700 \\
\hline OB2 & $\begin{array}{l}\text { Bacillus safensis KMF402 } \\
\text { (MT642941) }\end{array}$ & $\% 100$ & 700 \\
\hline OB6 & $\begin{array}{l}\text { Paenibacillus lactis PF4J_1-2 } \\
(\underline{\text { KT720088 })}\end{array}$ & $\% 100$ & 700 \\
\hline PT & $\begin{array}{l}\text { Exiguobacterium profundum } \\
\text { APBSMLB42 }^{\mathrm{T}} \text { (MG705821) }\end{array}$ & $\% 80$ & 600 \\
\hline İÇ1 & 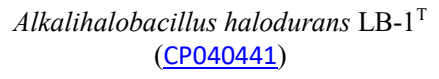 & $\% 100$ & 700 \\
\hline İÇ9 & $\begin{array}{l}\text { Brevibacillus agri ChemUPES_4 } \\
\text { (MK281590) }\end{array}$ & $\% 100$ & 700 \\
\hline UTÇ1 & $\begin{array}{l}\text { Bacillus paralicheniformis NYGR20 } \\
\text { (MN922812) }\end{array}$ & $\% 100$ & 700 \\
\hline
\end{tabular}

\subsection{Kalitatif Enzim Aktivitesi Tayini}

Otuz adet termofilik izolatın lipaz, amilaz, proteaz aktivite sonuçları Tablo 3'de verilmiştir. Toplamda 30 suş içinden lipaz enzimi aktivitesi açısından pozitif 15 , amilaz enzimi aktivitesi açısından pozitif 19 , proteaz enzimi aktivitesi açısından pozitif 17 adet suş tespit edilmiştir. 
Tablo 3. Izole Edilen Temofilik Bakterilerin Lipaz, Amilaz ve Proteaz Enzim Aktivitesi Açısından Kalitatif Bulgular

\begin{tabular}{|c|c|c|c|c|c|}
\hline Suş Adı & $\begin{array}{c}\text { 16S rDNA Blast } \\
\text { Sonucu }\end{array}$ & 己 & 동. & : & 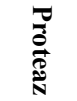 \\
\hline $\mathrm{KO} 1$ & Tepidicella xavieri & 1 & - & - & - \\
\hline $\mathrm{KO} 2$ & Tepidicella xavieri & 1 & - & - & - \\
\hline $\mathrm{KO} 3$ & Paracoccus aestuarii & 2 & ++ & - & - \\
\hline $\mathrm{OB} 2$ & Bacillus safensis & 3 & + & - & +++ \\
\hline OB3 & Bacillus safensis & 3 & - & +++ & ++++ \\
\hline OB4 & Bacillus safensis & 3 & ++ & - & +++ \\
\hline OB5 & Bacillus safensis & 3 & + & +++ & ++ \\
\hline OB6 & Paenibacillus lactis & 4 & + & - & - \\
\hline GTO & $\begin{array}{l}\text { Alkalihalobacillus } \\
\text { halodurans }\end{array}$ & 6 & ++ & + & ++ \\
\hline PT & $\begin{array}{c}\text { Exiguobacterium } \\
\text { profundum }\end{array}$ & 5 & - & +++ & +++ \\
\hline UTAH & $\begin{array}{c}\text { Exiguobacterium } \\
\text { profundum }\end{array}$ & 5 & + & ++ & - \\
\hline İÇ1 & $\begin{array}{c}\text { Alkalihalobacillus } \\
\text { halodurans }\end{array}$ & 6 & +++ & + & + \\
\hline İÇ2 & $\begin{array}{c}\text { Alkalihalobacillus } \\
\text { halodurans }\end{array}$ & 6 & - & - & - \\
\hline İÇ3 & $\begin{array}{c}\text { Alkalihalobacillus } \\
\text { halodurans }\end{array}$ & 6 & +++ & - & +++ \\
\hline İÇ4 & $\begin{array}{c}\text { Alkalihalobacillus } \\
\text { halodurans }\end{array}$ & 6 & - & +++ & + \\
\hline İÇ5 & $\begin{array}{c}\text { Alkalihalobacillus } \\
\text { halodurans }\end{array}$ & 6 & + & ++ & + \\
\hline İÇ6 & $\begin{array}{c}\text { Alkalihalobacillus } \\
\text { halodurans }\end{array}$ & 6 & - & +++ & + \\
\hline İÇ6C1 & $\begin{array}{c}\text { Alkalihalobacillus } \\
\text { halodurans }\end{array}$ & 6 & - & +++ & + \\
\hline İÇ6C2 & $\begin{array}{c}\text { Alkalihalobacillus } \\
\text { halodurans }\end{array}$ & 6 & - & +++ & - \\
\hline İÇ7 & $\begin{array}{c}\text { Alkalihalobacillus } \\
\text { halodurans }\end{array}$ & 6 & - & +++ & + \\
\hline İÇ8A & $\begin{array}{c}\text { Alkalihalobacillus } \\
\text { halodurans }\end{array}$ & 6 & - & - & - \\
\hline İÇ8B & $\begin{array}{c}\text { Alkalihalobacillus } \\
\text { halodurans }\end{array}$ & 6 & + & +++ & - \\
\hline İÇ9 & Brevibacillus agri & 7 & ++ & - & - \\
\hline UTÇ1 & $\begin{array}{c}\text { Bacillus } \\
\text { paralicheniformis }\end{array}$ & 8 & - & - & ++ \\
\hline UTÇ2 & $\begin{array}{c}\text { Bacillus } \\
\text { paralicheniformis }\end{array}$ & 8 & - & +++ & + \\
\hline UTÇ3 & $\begin{array}{c}\text { Bacillus } \\
\text { paralicheniformis }\end{array}$ & 8 & - & ++ & - \\
\hline UTÇ3G & $\begin{array}{c}\text { Bacillus } \\
\text { paralicheniformis }\end{array}$ & 8 & - & +++ & - \\
\hline UTÇ4A & $\begin{array}{c}\text { Bacillus } \\
\text { paralicheniformis }\end{array}$ & 8 & ++ & +++ & ++ \\
\hline UTÇ4B & $\begin{array}{c}\text { Bacillus } \\
\text { paralicheniformis }\end{array}$ & 8 & + & ++ & + \\
\hline UTÇ5 & $\begin{array}{c}\text { Bacillus } \\
\text { paralicheniformis }\end{array}$ & 8 & ++ & + & - \\
\hline
\end{tabular}

Kalitatif olarak lipaz, amilaz ve proteaz enzimleri açısından pozitif bulunan bazı suşların petri resimleri aşağıda verilmiştir.

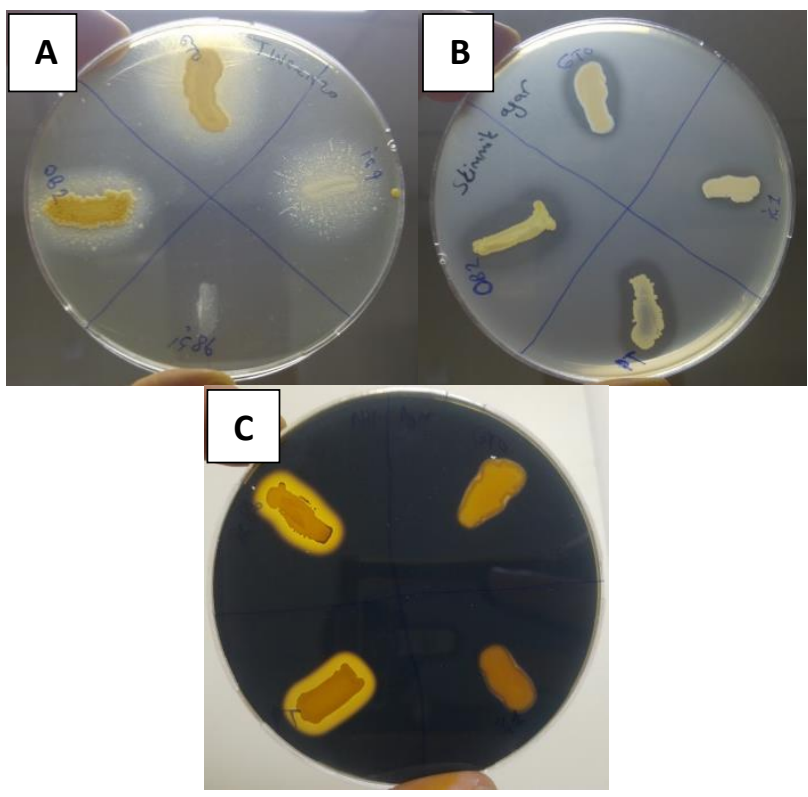

Şekil 2. A: Lipaz enzim aktivitesi, B: Proteaz enzim aktivitesi, C: Amilaz enzim aktivitesi açısından yüksek aktivite gösteren bazı suşlar

Dünyada var olan bölgesel sıcak kaynaklar olağandışı hayat, gen ve metabolit formları için önemli noktaları temsil etmektedir. Thomas Brock, Yellowstone Milli Parkı'nın termal bölgelerinden Thermus aquaticus'un varlığını keşfettiğinden beri, birçok araştırmacı tüm dünyada benzer ortamları araştırmış̧ır. Yaşadığımız dünya araştırmacıların hala identifikasyon ve izolasyonunu tamamlayamadığı çeşitli mikroorganizmalar ile doludur ve bu umut vaadeden mikroorganizmaları araştırmak için pek çok çalışma devam etmektedir (Mohammad ve ark., 2017). Çalışmamızda örnek toplanılan sıcak su alanlarından \% 83,3 oranında Bacillus cinsi izole edilmiştir. Bunun sebebi bu cinsin endosporlu ve çok çeşitli çevre şartlarına dirençli olmasından kaynaklanmaktadır (Connor ve ark., 2010).

$\mathrm{Bu}$ çalışmada sıcak su kaynaklarından izole edilen aynı türlere ait farklı suşların gelişimi $50^{\circ} \mathrm{C}$ sıcaklık şartlarında gerçekleştirilmiştir.

Çalışmamızda elde edilen izolatların lipaz, amilaz ve proteaz enzim aktivitelerine bakılmıştır. İÇ1 ve İÇ3 suşlarının çalışılan otuz izolat içerisinde en yüksek lipaz aktivitesine sahip olduğu tespit edilmiştir. Blastlama sonucuna göre Alkalihalobacillus halodurans $\mathrm{LB}-1^{\mathrm{T}}$ ile $\% 100$ benzerlik gösteren İÇ1 suşu izolatlar arasında en yüksek lipaz aktivitesi göstermiş̧tir. Çalışılan izolatlar kendi içinde karşılaştırıldığında OB3, OB5, PT, İÇ4, İÇ6, İÇ6C1, İÇ6C2 ve IÇC7 suşları amilaz enzim aktivitesi açısından en yüksek aktiviteyi göstermişlerdir. Exiguobacterium profundum ile \%80 benzerlik gösteren PT suşu çalışılan suşlar arasında en yüksek amilaz aktivitesine sahiptir. Yüksek proteaz enzim aktivitesine sahip OB2, OB3, OB4, PT ve İÇ3 suşları içinden OB3 suşunun otuz izolat içinde en yüksek proteaz enzim aktivitesine sahip olduğu tespit edilmiştir. Bacillus safensis ile \%100 benzerliğe sahip olan OB2, RFLP sonucuna göre yukardaki suşlar ile aynı DNA profiline sahip olduğu görülmüştür. Elde edilen termofilik izolatların büyük çoğunluğu Bacillus cinsine ait olduğu tespit edilmiştir. Bacillus cinsine ait türler ile yapılmış pek çok enzim çalışması literatürde bulunmaktadır (Nawani ve Kaur, 2007), Bacillus subtilis 168 (Lesuısse ve ark., 1993), Bacillus 
thermoleovorans CCR11(Castro-Ochoa ve ark., 2005), Bacillus sphaericus 205y (Sulong ve ark., 2006) ve Anoxybacillus flavithermus HBB 134 (Bakir ve Metin, 2016) gibi birçok Bacillus türünde lipaz aktivitesine bakılmıştır. Bizim çalışmamızda Aydın ve Denizli sıcak su kaynaklarından izole edilen termofilik bakteri, Alkalihalobacillus halodurans'in çalışılan otuz izolat arasında en yüksek lipaz aktivitesine sahip olduğu tespit edilmiştir. Chang ve ark. tarafından yapılan çalışmada, 16S rDNA sekans analizi sonucu a-amilaz enzimi elde edilen DAU5 suşunun Exiguobacterium profundum 10C

\section{Sonuç}

Aydın ve Denizli çevresinden izole edilmiş termofilik bakterilerden lipaz, amilaz ve proteaz enzim aktiviteleri görüntülenmiştir. Otuz izolat içerisinde yüksek enzim aktivitelerine sahip birçok suş tespit edilmiştir. Otuz izolat arasında enzimleri üreten suşların yüzdesi; lipaz \% 50, amilaz \% 63.3, proteaz \% 56.6 dır. Lipaz-proteaz üreten 3, amilaz-proteaz üreten 7 izolatın her iki enzimi ürettiği tespit edilmiştir. Lipazamilaz-proteaz üreten 6 izolatın her üç enzimi ürettiği tespit edilmiştir. Çalışmadaki bazı Bacillus halodurans ve Bacillus paralicheniformis suşlarının üçlü enzim üretimi yaptığı bununla birlikte diğer bazı, Bacillus safensis, Exiguobacterium profundum, Bacillus halodurans, Bacillus paralicheniformis suşlarının da ikili enzim üretimi yaptığı tespit edilmiştir.

Sonuç olarak, bu çalışmada elde edilen suşların ürettiği enzimler termostabil olduklarından endüstriyel açıdan yüksek değere sahiptir. İlaç, gıda, temizlik, deri, katı atık arıtma, kağıt ve tekstil endüstrilerinde kullanım potansiyeline sahiptir.

\section{Kaynakça}

ANONIM. Kaplıcaya Sahip Belediyeler Birliği. (2001).

Baker, G. C., Gaffar, S., Cowan, D. A., \& Suharto, A. R. (2001). Bacterial community analysis of Indonesian hot springs. FEMS Microbiology Letters, 200(1), 103-109.

Bakir, Z. B., \& Metin, K. (2016). Purification and characterization of an alkali-thermostable lipase from thermophilic Anoxybacillus flavithermus HBB 134. Journal of Microbiology and Biotechnology, 26(6), 1087-1097.

Başbülbül G., Dabanca M. B., Kaya K. G., Oryaşın E. ve Bozdoğan B. (2018). Acıgöl (Denizli)'den İzole Edilen Alkalifilik Bakterilerin Enzimatik Aktivitelerinin Araştırılması. 1st International Health Science And Life Congress (IHSLC 2018).

Castro-Ochoa, L. D., Rodríguez-Gómez, C., Valerio-Alfaro, G., \& Ros, R. O. (2005). Screening, purification and characterization of the thermoalkalophilic lipase produced by Bacillus thermoleovorans CCR11. Enzyme and Microbial Technology, 37(6), 648-654.

Chang, J., Lee, Y. S., Fang, S. J., Park, I. H., \& Choi, Y. L. (2013). Recombinant expression and characterization of an organicsolvent-tolerant $\alpha$-amylase from Exiguobacterium sp. DAU5. Applied Biochemistry and Biotechnology, 169(6), 1870-1883.

Connor, N., Sikorski, J., Rooney, A. P., Kopac, S., Koeppel, A. F., Burger, A., ... \& Cohan, F. M. (2010). Ecology of speciation in the genus Bacillus. Applied and Environmental Microbiology, 76(5), 1349-1358. bakterisine \%99 oranında benzerliği tespit edilmiştir (Chang ve ark., 2013). Bu çalışmada ise Exiguobacterium profundum suşundan yüksek amilaz aktivitesi tespit edilmiştir. Rekik ve arkadaşları tarafından Bacillus safensis RH12 suşundan serin alkalin proteaz enzimi elde edilmiş ve ticari çamaşır deterjanlarında \%100 stabil kaldığı bildirilmiştir (Rekik ve ark., 2019). Bizim çalışmamızda OB3 koduna sahip olan ve en yüksek homolojiyi Bacillus safensis türü ile gösteren izolatımızda yüksek proteaz aktivitesi görüntülenmiştir.

de Souza, P. M. \& e Magalhães, P. de O. (2010). Application of microbial $\alpha$-amylase in industry - a review. Brazilian Journal of Microbiology 41, 850-861.

Fitrianı, S., \& Güven, K. (2018). Isolation, screening, partial purification and characterization of protease from halophilic bacteria isolated from Indonesian fermented food. Anadolu Üniversitesi Bilim ve Teknoloji Dergisi-C Yaşam Bilimleri Ve Biyoteknoloji, 7(2), 130-142.

Güven, R. G. (2011). Termofilik bakteriler ve biyoteknolojik açıdan önemli bazı enzimleri. Elektronik Mikrobiyoloji Dergisi TR, 9(1), 1-10.

Lessuise, E., Schanck, K., \& Colson, C. (1993). Purification and primary characterization of the extracellular lipase of Bacillus subtilis 168, an extreme basic tolerant enzyme. Eur. J. Biochem, 216, 155-160.

Mohammad, B. T., Al Daghistani, H. I., Jaouani, A., Abdel-Latif, S., \& Kennes, C. (2017). Isolation and characterization of thermophilic bacteria from Jordanian hot springs: Bacillus licheniformis and Thermomonas hydrothermalis isolates as potential producers of thermostable enzymes. International journal of microbiology, 2017.

Nawani, N., \& Kaur, J. (2007). Studies on lipolytic isoenzymes from a thermophilic Bacillus sp.: Production, purification and biochemical characterization. Enzyme and Microbial Technology, 40(4), 881-887.

Royter, M., Schmidt, M., Elend, C., Höbenreich, H., Schäfer, T., Bornscheuer, U. T., \& Antranikian, G. (2009). Thermostable lipases from the extreme thermophilic anaerobic bacteria Thermoanaerobacter thermohydrosulfuricus SOL1 and Caldanaerobacter subterraneus subsp. tengcongensis. Extremophiles, 13(5), 769-783.

Ramnath, L., Sithole, B., \& Govinden, R. (2017). Identification of lipolytic enzymes isolated from bacteria indigenous to Eucalyptus wood species for application in the pulping industry. Biotechnology Reports, 15, 114-124.

Rekik, H., Jaouadi, N. Z., Gargouri, F., Bejar, W., Frikha, F., Jmal, N., ... \& Jaouadi, B. (2019). Production, purification and biochemical characterization of a novel detergent-stable serine alkaline protease from Bacillus safensis strain RH12. International Journal of Biological Macromolecules, 121, 1227-1239.

Sulong, M. R., Rahman, A., \& RN, S. AB, \& Basri, MA (2006). Novel organic solvent tolerant lipase from Bacillus sphaericus 205y: extracellular expression of a novel OSTlipase gene. Protein Expression and Purification, 49(2), 190195. 